\title{
Influence of Beauty Care on Well-being-Oriented Behaviors and Well-Aging Behaviors in Adult Men
}

Jae-Young Park, Myung-Sun Lee

Department of Beauty \& Health Care, Daejeon University, Daejeon, Korea

\author{
"Corresponding author: Myung-Sun Lee, \\ Department of Beauty \& Health care, \\ Daejeon University, 62, Daehak-ro, Dong- \\ gu, Daejeon 34520, Korea \\ Tel.: +8242 2802393 \\ Fax: +82422802783 \\ Email: leesun1460@hanmail.net
}

\section{Received December 24, 2018}

Revised February 22, 2019

Accepted March 5, 2019

Published March 30, 2019

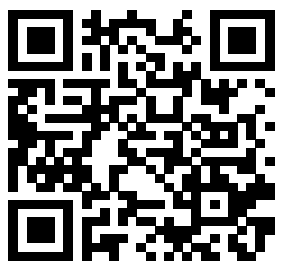

\begin{abstract}
Purpose: This study aims to examine the influence of beauty care regimens of adult men on their well-being-oriented behaviors and well-aging behaviors in order to explore the creation and/or maintenance of mental and physical health, thereby improving overall quality of life. Method: The collected data was analyzed by an SPSS program. The main analytical methods used were frequency and percentage. These were calculated to grasp the general characteristics of the subjects, and one-way ANOVA, $t$-tests and regression analyses were conducted to determine the efficacy of beauty care on well-being-oriented and well-aging behaviors. Results: Beauty care regimens of adult men had a significant positive correlation with both well-being-oriented and well-aging behaviors ( $r=0.507, p<0.001 ; r=0.614, p<0.001$, respectively); more beauty care led to greater well-being-oriented as well as wellaging behaviors. Conclusion: The findings illustrated that younger men cared more about beauty care and well-aging and that beauty care was correlated with wellaging behaviors and well-being-oriented behaviors. The right awareness of well-being and proper beauty care are necessary to ensure the health of the mind and body and to improve the standard of living across society in pursuit of a happy, healthy life.
\end{abstract}

Keywords: Well-aging behavior, Beauty care, Well-aging, Well-being awareness, Wellbeing oriented behavior

\section{Introduction}

삶의 질(quality of life)이란 인간 삶의 내용을 다루는 개념 으로 인간의 가치와 관련되는 개념이기 때문에 인간 삶의 다 양한 측면에 대해 상이한 평가가 이루어질 수 있어서 삶의 질 을 주관적·심리적 안녕(psychological well-being), 행복감 (happiness), 생활만족도(life satisfaction)와 동의어로 볼 수 있다. 이는 사람마다 각자가 생각하는 행복한 삶의 기준은 다르 며 더 나은 삶을 살아가는 방식도 다르다.

다양한 방식 중의 하나인 웰빙(Well-being)은 몸과 마음이 유 기적으로 결합된 풍요롭고 아름다운 인생을 영위하자는 새로운 라이프스타일의 하나로써, 잘먹고 잘사는것, 건강하고 여유롭게 사는 것이 중요하며, 물질보다 정신을 중시하고, 여유로운 생활 을 추구하는 것을 의미한다(Kwock \& Jang, 2008).

웰빙(Well-being)은 외모관리와 신체의 건강을 위한 행동으
로 이어지게 되며, 이는 아름다운 외모를 가지고 아름다운 노 년을 영위하는 것 역시 웰빙의 조건으로 인식하고 있다(Kim et al., 2012). 아름다운 외모를 중시하는 사회가치와 신념은 외적 인 아름다움을 추구하던 때와 달리 현대에는 내적 아름다움을 가 꾸기 위해 다양한 개발과 관리를 하기위해 노력하는 것으로 바 뀌고 있다. 이는 남, 여 그리고 연령 상관없이 건강에 대한 높은 관심으로 인한 여가 스포츠 활동, 건강 지향인 식생활, 웰빙행동 등이 기여한 부분이다.

현대에 들어 경제성장과 더불어 생활수준의 향상으로 성취 지 향적 삶과 인터넷 등을 통한 다양한 지식정보를 얻을 수 있게 되 면서 선진국형 라이프 스타일이 집입하고 있다.

급변하는 다양한 변화속에 여성적행위로 간주되어 왔던 외모 관리에 대한 남성들의 태도가 변화되고(Park, 2015) 있었으며, 이는 자신을 꾸미는 남성 글루밍(glooming)족이라 부르며 남성 들까지 외모에 투자를 하고, 먹고 마시는 것 하나도 건강과 영양 
을 고려해 꼼꼼히 선택하는 헬시(healthy)족이 증가하고 있다. 남성들의 외모에 관심을 서서히 보이기 시작한 시기로는 2009년 도에 통계청에서 국가통계 분석자료를 기반으로 경쟁이 없는 시 장의 새로운 소비자를 찾아낸 '블루슈머(blue ocean consumer) 10 '의 하나로 '거울 보는 남자(gooming)'를 선정한 것이 그 대표 적인 예이다(Kim \& Shin, 2018).

남성 뷰티에디터가 다양한 남성용 화장품과 피부 관리 방법에 대하여 설명하는 것을 쉽게 볼 수 있으며, 남성들만을 위한 상품 과 정보들이 홍수처럼 쏟아져 나오고 있다(Kwon 2016).

남성들은 자신의 피부에 대한 케어를 단순히 미용적 개념에 서 벗어나 '자기관리'에서 오는 능력으로 생각하고 있으며(Hong, 2008), 외모에 대한 중요성이 부각되면서 자기애, 자존감의 향 상 및 사회적인 이미지 구축을 위해 과거보다 좀 더 다양하고 세 분화된 뷰티관리행동을 통하여 자신의 기대 이미지에 부응하기 위하여 시간과 비용, 노력을 아끼지 않는다(Hong, 2013).

미용관리는 다른 사람에게 호감을 주기 위한 요소로 자신의 결 점이나 정신적 콤플렉스를 극복하기 위해 다양한 미용관리 행동 을 하며, 그로 인해 외모에 있어 긍정적인 자아개념을 가진 자들 은 안정감과 자신감을 갖게 되어 대인관계에서도 긍정적이며 적 극적인 자세를 형성하며 타인에게도 좋은 이미지로 인식되고 인 정되어 외모관리행동은 자기만족과 대인관계에 있어서도 밀접한 관계가 있음을 보여주고 있다(Kim, 2007). 외모는 바디 사이즈, 바디 유형, 비만도와 같은 전반적인 신체 특징, 얼굴, 가슴 등의 특정 신체부위와 관련된 요인들, 의류와 액세서리, 헤어 스타일 링 등 다양한 요소로 구성되어 자신과 타인에 의해 지각된다(Yu \& Ko, 2016).

$\mathrm{Yu} \& \mathrm{Ko}$ (2016)의 연구에서는 삶의 질이 높은 집단이 낮은 집단에 비해 신체 요인인 얼굴, 체중, 몸매, 신체비례, 헤어, 전 반적인 인상에 대한 만족도가 높게 나타났으며, 외모관련 삶의 질이 낮은 집단일수록 body mass index (BMI)가 높으며 이는 비만도가 높은 집단의 삶의 질이 낮다는 것을 알 수 있다.

이처럼 외모관리는 현대인의 중요한 관심사 중 하나로 어떻게 관리되는가에 따라서 그 사람의 외적이미지가 결정되는데(Hong $\& \mathrm{Kim}, 2012)$, 아름다운 외모, 건강한 신체, 능수능란한 사교술 패션스타일 등은 사람을 매력적인 존재로 만드는 '조용한 권력'이 라는 것이다(Kim \& Shin, 2018).

건강한 피부라 할지라도 끓임없는 외부의 자극이나 스트레스, 잘못된 관리 방법, 불규칙한 생활습관이나 식습관, 피부에 맞
지 않는 화장품 사용으로 인해 순간 민감해 질 수 있다(Kim \& Shin, 2018). 더구나 남성은 여성의 피부에 비해 두꺼운 피부층 을 가지고 있으며, 성인 남성들이 대부분 경험하는 면도로 인해 각질층이 손상되고, 피부를 보호하는 천연 피지막이 손실되며 잘 못된 면도 습관으로 인해 피부의 유·수분 밸런스를 깨뜨려 예민 한 피부를 가지게 된다(Kwon, 2016). 이에 남성들의 건강하고 생기있는 피부를 위해서는 피부에 대한 상식과 자신의 피부에 대 한 정확한 관리법을 알고 그에 맞는 적절한 화장품을 사용하는 것도 필요하다(Lim \& Kim, 2015). Kim et al. (2012)의 연구 에서는 웰빙인식이 외모관리행동을 설명한 총설명력은 $25 \%$ 로 파악되었으며, 웰빙인식이 외모관리행동에 통계적으로 유의한 $(F=108.05, p<0.001)$ 정적 영향 $(\beta=0.50, t=10.40, p<0.001)$ 을 미치는 것으로 웰빙인식이 높을수록 외모관리 행동의 빈도가 더 높다는 것을 나타났다. Jeon \& Jae (2007)의 연구에서는 내 가족이 건강하다고 인식할수록, 웰빙 식생활이 환경을 고려하는 것이라고 인식할수록, 그리고 웰빙 식생활관련 정보에 관심이 높 을수록 웰빙 지향 사용행동을 많이 한다는 결과가 나타났다.

인간의 미(美)는 내적인 아름다움과 외적인 아름다움이 조화 롭게 어우러져야 진정한 아름다움이라고 사람들은 일반적으로 생각(Hwang et al., 2017)하며, 웰빙 열풍으로 건강에 대한 관 심이 점점 더 높아지고 있으며, 이에 따라 헬스, 수영, 요가 등의 운동을 하는 국민이 증가하고 있다. 체형은 선천적인 요인뿐만 아니라 반복된 운동과 자세 또는 식생활 습관 등으로 인해 후천 적으로도 큰 변화를 가져오므로 개인차가 심하다(Jeong \& Kim, 2008). 웰빙과 관련된 연구들은 있으나 남성을 대상으로한 웰빙 과 미용에 대한 연구들은 미비한 편이다.

웰빙행동과 웰에이징 관리로 몸과 마음의 건강을 통하여 아름 다운 삶을 추구하여 사회 전반적 생활 수준을 향상시키기 위하여 올바른 웰빙(well-being)인식과 미용관리가 필요하다고 사료된 다. 이에 본 연구는 성인 남성의 미용관리가 웰빙지향행동과 웰 에이징 관리에 미치는 영향과 관련성을 알아보고자 한다.

\section{Methods}

\section{1. 연구대상 및 자료수집}

본 연구의 분석을 위해 경북 지역의 성인 남성을 조사대상으 로 연구의 목적을 설명한 후에 자기기입식 설문을 실시하였다.

Table 1. Survey reliability

\begin{tabular}{lcc}
\hline Classification & Number of questions & Cronbach's $\alpha$ \\
Beauty care & 15 & 0.93 \\
Well-being oriented behavior & 26 & 0.91 \\
Well-aging behavior & 15 & 0.89 \\
\hline
\end{tabular}


2018년 10월 08일부터 2018년 11월 10일까지 배포하여 수거 된 총 250 부의 설문지 중 분석에 사용되기 불충분하다 판단되는 7 부를 제외한 243 부가 최종 분석자료로 사용되었다.

\section{2. 측정 항목 및 내용}

본 연구의 자료 수집을 위해 설문지법이 사용되었다. 측정도구
로 사용된 설문문항은 크게 일반적 특성, 미용관리 15 문항으로 선행연구(Kim \& Youn, 2007)를 수정, 보완하였으며, 웰빙지향 행동 26 문항으로 선행연구 (Kim \& Kim, 2008)를 수정, 보완하 여 구성하였다. 또한 웰에이징 행위 15 문항으로 선행연구(Kim $\& \mathrm{Kim}, 2006)$ 를 수정,보완하여 구성하였다.

미용관리는 각 문항의 응답범주는 '전혀그렇지 않다', '그렇지

Table 2. Research subjects' general characteristics

\begin{tabular}{|c|c|c|c|}
\hline Classification & & Frequency $(\mathrm{N})$ & Percentage (\%) \\
\hline \multirow{4}{*}{ Age } & $20 s$ & 70 & 28.8 \\
\hline & $30 s$ & 70 & 28.8 \\
\hline & $40 s$ & 53 & 21.8 \\
\hline & $50 s$ & 50 & 20.6 \\
\hline \multirow{4}{*}{ Academic background } & High school diploma or lower & 71 & 29.2 \\
\hline & Junior college graduate & 69 & 28.4 \\
\hline & University school graduate & 95 & 39.1 \\
\hline & Over graduate school & 8 & 3.3 \\
\hline \multirow{7}{*}{ Job } & Retail or service worker & 35 & 14.4 \\
\hline & Office manager/civil servant & 45 & 18.5 \\
\hline & Self-employed/business & 24 & 9.9 \\
\hline & Student & 31 & 12.8 \\
\hline & Production/technician & 65 & 26.7 \\
\hline & Profession & 22 & 9.1 \\
\hline & Others & 21 & 8.6 \\
\hline \multirow{6}{*}{ Monthly household income } & Under 1,000,000 won & 33 & 13.6 \\
\hline & $1,000,000-1,990,000$ won & 36 & 14.8 \\
\hline & $2,000,000-2,990,000$ won & 90 & 37.0 \\
\hline & $3,000,000-3,990,000$ won & 38 & 15.6 \\
\hline & $4,000,000-4,990,000$ won & 25 & 10.3 \\
\hline & Over $5,000,000$ won & 21 & 8.6 \\
\hline \multirow{2}{*}{ Marital status } & Unmarried & 117 & 48.1 \\
\hline & Married & 126 & 51.9 \\
\hline \multirow{4}{*}{ A day's smoking } & Non-smoker & 125 & 51.4 \\
\hline & Under 2/1 pack & 34 & 14.0 \\
\hline & Under 2/1-1 pack & 54 & 22.2 \\
\hline & Over 1 pack & 30 & 12.3 \\
\hline \multirow{4}{*}{ Number of drinks } & Seldom drink & 89 & 36.6 \\
\hline & Once or twice a week & 95 & 39.1 \\
\hline & Three to five times a week & 49 & 20.2 \\
\hline & Six to seven times a week & 10 & 4.1 \\
\hline \multirow{6}{*}{ Monthly average beauty care costs } & Under 100,000 won & 169 & 69.5 \\
\hline & $100,000-u n d e r 200,000$ won & 32 & 13.2 \\
\hline & $200,000-$ under 300,000 won & 22 & 9.1 \\
\hline & $300,000-$ under 400,000 won & 12 & 4.9 \\
\hline & 400,000-under 500,000 won & 4 & 1.6 \\
\hline & Over 500,000 won & 4 & 1.6 \\
\hline \multirow{4}{*}{ Body type } & Endomorphy & 76 & 31.3 \\
\hline & Mesomorphy & 129 & 53.1 \\
\hline & Ectomorphy & 38 & 15.6 \\
\hline & Total & 243 & 100.0 \\
\hline
\end{tabular}


않은 편이다', '그저 그렇다', '그런 편이다', '전적으로 그렇다'로 범주화한 5 점 척도로 구성하여 문항이 총 15 문항이며, 점수가 높을수록 미용관리가 높다. 웰빙 지향 행동은 각 문항의 응답범 주는 '전혀아니다', '아니다', '보통이다', '그렇다', '매우그렇다'로 범주화한 5 점 척도로 구성하여 점수가 높을수록 웰빙 지향 행동 을 많이 하는 것으로 구성, 웰 에이징 행위는 각 문항의 응답범주 는 '그렇다', '때때로 한다', '그렇지 않다'로 범주화한 3점 척도로 구성하여 점수가 높을수록 웰 에이징행위가 높은 것으로 하였다.

\section{1) 측정도구}

본 연구의 측정도구의 신뢰도를 검증한 결과는 Table 1 에 제 시한 바와 같이 Cronbach's $\alpha$ 가 미용관리 0.93 , 웰빙지향 행동 0.91 , 웰에이징 행위 0.89 로, 모두 0.80 이상으로 나타나 본 연 구의 측정도구는 신뢰할만한 수준임을 알 수 있다.

\section{3. 분석방법}

본 연구의 수집된 자료는 Statistical Package for the Social Science (SPSS) WIN 23.0 프로그램(IBM, USA)을 이용하여 분석하였다. 연구대상자의 일반적 특성을 파악하기 위해 빈도와 백분율을 산출하였고, 성인 남성들의 미용관리와 웰빙지향 행동, 그리고 웰에이징 행위를 살펴보기 위해 일원변량분석(one-way $\mathrm{ANOVA}$ )과 $t$-test (검증)을 실시하였다. 또한 성인 남성들의 미 용관리와 웰빙지향 행동 및 웰에이징 행위와의 관계를 파악하기 위해 상관관계분석(correlation)을 실시하였으며, 성인 남성들의 미용관리가 웰빙지향 행동과 웰에이징 행위에 미치는 영향을 알 아보기 위해 regression (회귀분석)을 실시하였다.

\section{Results and Discussion}

\section{1. 조사대상자의 일반적 특성}

조사대상자의 일반적 특성에 대해 알아보기 위하여 빈도분석 을 실시한 결과 Table 2 와 같다.

총 243 명 중 연령별로는 20 대와 30 대가 각각 $28.8 \%$ 를 차지 하였고, 40 대는 $21.8 \%, 50$ 대는 $20.6 \%$ 이었다. 학력별로는 대 졸이 $39.1 \%$ 로 가장 많았으며, 다음으로 고졸 이하 $29.2 \%$, 전문 대졸 $28.4 \%$, 대학원졸 $3.3 \%$ 순으로 나타났다. 직업별로는 생 산/기술직이 $26.7 \%$ 로 가장 높은 분포를 보였으며, 다음으로 사 무관련직/공무원 $18.5 \%$, 영업/서비스업 $14.4 \%$, 학생 $12.8 \%$, 자영업/사업 $9.9 \%$, 전문직 $9.1 \%$, 기타 $8.6 \%$ 순으로 나타났 다. 월평균 소득별로는 200-299만원이 $37.0 \%$ 로 가장 높은 분 포를 보였으며, 다음으로 $300-399$ 만원 $15.6 \%, 100-199$ 만 원 $14.8 \%, 100$ 만원 미만 $13.6 \%, 400-499$ 만원 $10.3 \%, 500$ 만 원 이상 $8.6 \%$ 순이었다. 결혼상태별로는 기혼이 $51.9 \%$ 로 미혼
48.1\%보다 많았다. 하루 흡연량별로는 담배를 피우지 않는 남성 이 $51.4 \%$ 로 절반 이상을 차지하였으며, 다음으로 2/1-1갑 미만 $22.2 \%, 2 / 1$ 갑 미만 $14.0 \%, 1$ 갑 이상 $12.3 \%$ 순으로 나타났다. 음주횟수별로는 주 1-2회가 $39.1 \%$ 로 가장 많았으며, 다음으로 주 3-5회 $20.2 \%$, 주 6-7회 $4.1 \%$ 순이었고, 술을 마시지 않는 남성은 $36.6 \%$ 를 차지하였다.

월평균 외모관리 비용별로는 10 만원 미만이 $69.5 \%$ 로 가장 높 은 분포를 보였으며, 다음으로 10-20만원 미만 $13.2 \%, 20-30$ 만원 미만 $9.1 \%, 30-40$ 만원 미만 $4.9 \%$ 순이었다. 체형별로는 중배엽이 $53.1 \%$ 로 절반 이상이었으며, 다음으로 내배엽 $31.3 \%$, 외배엽 $15.6 \%$ 순으로 나타났다.

\section{2. 성인 남성의 미용관리, 웰빙지향 행동, 웰에이징 행위}

1) 미용관리

성인 남성들의 미용관리 정도에 대해 살펴본 결과는 Table 3 과 같이 5 점 만점 중 전체 평균이 2.85 로, 성인 남성들은 미용관 리가 그다지 높지 않은 것으로 나타났다.

연령별로는 20 대 남성이 미용관리가 가장 높았고, 40 대 남성 은 다른 연령대 남성보다 미용관리가 낮았으나 유의미한 차이는 아니었다.

학력별로는 전문대졸인 남성이 미용관리가 가장 높았고, 고졸 이하인 남성은 다른 학력의 남성보다 미용관리가 낮았으나 학력 에 따른 유의미한 차이가 없었다. Yim \& Kim (2014)연구에서 는 남성들의 미용관리에 대한 관심 정도가 5 점 만점 중 전체 평 균이 3.19 로, 관심이 높은 것으로 나타났으며, 대졸 남성이 미용 에 대한 관심이 가장 높아서 학력에 따라 유의미한 차이를 보였 다( $F=7.33, p<0.01)$. Lim et al. (2017)연구에서는 남성이 학 력이 높을수록, 나이가 적을수록 건강한 체중감량 행위를 하는 경향이 있었다.

직업별로는 학생이 미용관리가 가장 높았고, 기타 직업에 종사 하는 남성은 다른 직업에 종사하는 남성보다 미용관리가 낮았으 나 통계적으로는 유의미한 차이를 보이지 않았다.

Kim \& Youn (2007)연구에서 연령이 낮을수록 미용관리 행위 가 높음을 알 수 있는 것으로 본 연구와 같은 연구결과이다. 쉽고 빠르게 다양한 정보를 얻을 수 있는 젊은 남성들은 외모가 경쟁 력의 한 부분으로 보고 있는 현사회를 살아가기 위해 자기관리를 통한 자신의 매력을 업그레이드 시킴으로써 자신감을 찾게 되는 부분이다.

월평균 소득별로는 300 만원 이상인 남성이 미용관리가 가장 높았고, 200-299만원인 남성은 다른 남성보다 미용관리가 낮았 으나 유의미한 차이는 아니었다. Yim \& Kim (2014) 연구에서 는 월평균 수입이 500 만원 이상인 남성일수록 한달에 평균 화장 품 구매에 많은 지출을 한다는 결과를 보였다.

결혼상태별로는 미혼인 남성이 기혼인 남성보다 미용관리가 
높았으나 결혼상태에 따른 유의미한 차이가 없었다. Yim \& Kim (2014)연구에서 미혼 남성이 기혼 남성보다 미용관리에 대한 관 심이 높았으며, 본 연구와 비슷한 결과가 나타난 것으로 아무래 도 이성에게 잘 보이고 싶은 미혼 남성들이 미용관리에 더욱 관 심이 높음을 알 수 있다.

흡연여부별로는 담배를 피우지 않는 남성이 피우는 남성보다 미용관리가 높았으나 통계적으로는 유의미한 차이를 보이지 않 았다. 음주여부별로는 술을 거의 마시지 않는 남성이 마시는 남 성보다 미용관리가 높았으나 유의미한 차이는 아니었다.

월평균 외모관리 비용별로는 10-20만원 미만인 남성이 미용 관리가 가장 높았고, 10 만원 미만인 남성은 다른 남성보다 미용 관리가 낮았으며, 월평균 외모관리 비용에 따라 유의미한 차이를 보였다 $(F=4.15, p<0.05)$. 체형별로는 중배엽 체형의 남성이 미
용관리가 가장 높았고, 내배엽 체형의 남성은 다른 체형의 남성 보다 미용관리가 낮았으며, 체형에 따라 유의미한 차이를 보였다 ( $F=8.45, p<0.001)$. Chung (2011)연구 결과에서도 외모관리 를 하는 이유로는 자기만족을 위해서가 $51.1 \%$, 이성에게 호감을 위해서 $21.5 \%$ 로 나타났다.

Kim \& Cho (2010)는 남녀 대학생의 미용관리 및 체중관리에 대한 연구를 한 결과 남학생의 경우 매체의 영향력이 높고, 신체 에 대한 감시성(body surveillance)정도가 크고 외모에 대한 사 회적 인식 정도가 높을수록 미용관리에 대한 의도가 높아진다는 연구 결과가 나왔다. 체중관리는 남녀 대학생 모두 외모에 대한 사회적 인식이 높은 경우에 적극적인 체중관리를 하고자 한다는 것을 알 수 있는 결과로서 매체의 영향력과 함께 외모에 대한 사 회적 인식이 체중관리의도에 미치는 강력한 영향 변수임을 알 수

Table 3. Beauty care

\begin{tabular}{|c|c|c|c|c|c|c|}
\hline Classification & & $\mathrm{N}$ & Mean & $\mathrm{SD}$ & For $t$ & $p$ \\
\hline \multirow{4}{*}{ Age } & $20 \mathrm{~s}$ & 70 & 2.96 & 0.87 & \multirow{4}{*}{1.22} & \multirow{4}{*}{0.303} \\
\hline & $30 \mathrm{~s}$ & 70 & 2.83 & 0.75 & & \\
\hline & $40 \mathrm{~s}$ & 53 & 2.69 & 0.85 & & \\
\hline & $50 s$ & 50 & 2.91 & 0.72 & & \\
\hline \multirow{3}{*}{ Academic background } & High school diploma or lower & 71 & 2.80 & 0.87 & \multirow{3}{*}{0.40} & \multirow{3}{*}{0.67} \\
\hline & Junior college graduate & 69 & 2.92 & 0.73 & & \\
\hline & University graduation or above & 103 & 2.84 & 0.80 & & \\
\hline \multirow{7}{*}{ Job } & Retail or service worker & 35 & 2.98 & 0.85 & \multirow{7}{*}{1.28} & \multirow{7}{*}{$0.26 s$} \\
\hline & Office manager/civil servant & 45 & 2.73 & 0.87 & & \\
\hline & Self-employed/business & 24 & 2.91 & 0.64 & & \\
\hline & Student & 31 & 3.00 & 0.86 & & \\
\hline & Production/technician & 65 & 2.86 & 0.76 & & \\
\hline & Profession & 22 & 2.92 & 0.83 & & \\
\hline & Others & 21 & 2.49 & 0.71 & & \\
\hline \multirow{5}{*}{ Monthly household income } & Under $1,000,000$ won & 33 & 2.82 & 0.92 & \multirow{5}{*}{0.55} & \multirow{5}{*}{0.695} \\
\hline & $1,000,000-1,990,000$ won & 36 & 2.86 & 0.87 & & \\
\hline & $2,000,000-2,990,000$ won & 90 & 2.77 & 0.77 & & \\
\hline & $3,000,000-3,990,000$ won & 38 & 2.95 & 0.75 & & \\
\hline & Over 400,000 won & 46 & 2.95 & 0.78 & & \\
\hline \multirow{2}{*}{ Appearance of marital status } & Unmarried & 117 & 2.91 & 0.84 & \multirow{2}{*}{1.04} & \multirow{2}{*}{0.301} \\
\hline & Married & 126 & 2.80 & 0.77 & & \\
\hline \multirow{2}{*}{ Smoking } & Non-smoker & 125 & 2.95 & 0.78 & \multirow{2}{*}{1.91} & \multirow{2}{*}{0.057} \\
\hline & Smoker & 118 & 2.75 & 0.82 & & \\
\hline \multirow{2}{*}{ Drinking } & Seldom drink & 89 & 2.94 & 0.83 & \multirow{2}{*}{1.23} & \multirow{2}{*}{0.222} \\
\hline & Drink & 154 & 2.80 & 0.79 & & \\
\hline \multirow{3}{*}{$\begin{array}{l}\text { Monthly average } \\
\text { beauty care costs }\end{array}$} & Under 100,000 won & 169 & 2.77 & 0.79 & \multirow{3}{*}{$4.15^{*}$} & \multirow{3}{*}{0.017} \\
\hline & Under $100,000-200,000$ won & 32 & 3.20 & 0.68 & & \\
\hline & Over 200,000 won & 42 & 2.93 & 0.86 & & \\
\hline \multirow{4}{*}{ Body type } & Endomorphy & 76 & 2.58 & 0.86 & \multirow{3}{*}{$8.45^{* * *}$} & \multirow{3}{*}{0.000} \\
\hline & Mesomorphy & 129 & 3.04 & 0.73 & & \\
\hline & Ectomorphy & 38 & 2.76 & 0.76 & & \\
\hline & Total & 243 & 2.85 & 0.80 & & \\
\hline
\end{tabular}

${ }^{*} p<0.05 ;{ }^{* * *} p<0.001$. 
있다고 하였다.

이상과 같이 성인 남성들은 미용관리가 그다지 높지 않았으며, 월평균 외모관리로 10-20만원 미만 지출하는 남성과 중배엽 체 형의 남성이 다른 남성보다 미용관리가 높았다.

\section{2) 웰빙지향 행동}

성인 남성들의 웰빙지향 행동에 대해 살펴본 결과는 Table 4 와 같이 5 점 만점 중 전체 평균이 2.35 로, 성인 남성들은 웰빙지 향 행동이 그다지 높지 않은 것으로 나타났다.

연령별로는 50 대인 남성이 웰빙지향 행동이 가장 높았고, 20 대인 남성은 다른 연령대 남성보다 웰빙지향 행동이 낮았으며, 연령에 따라 유의미한 차이를 보였다 $(F=10.85, p<0.001)$.

학력별로는 전문대졸인 남성이 웰빙지향 행동이 가장 높았고,
고졸 이하인 남성은 다른 학력의 남성보다 웰빙지향 행동이 낮았 으나 유의미한 차이는 아니었다.

직업별로는 자영업/사업에 종사하는 남성이 웰빙지향 행동이 가장 높았고, 학생은 다른 직업에 종사하는 남성보다 웰빙지향 행동이 낮았으나 직업에 따른 유의미한 차이가 없었다.

월평균 소득별로는 400 만원 이상인 남성이 웰빙지향 행동이 가장 높았고, 100 만원 미만인 남성은 다른 남성보다 웰빙지향 행동이 낮았으며, 월평균 소득에 따라 유의미한 차이를 보였다 $(F=3.73, p<0.01)$.

결혼상태별로는 기혼인 남성이 미혼인 남성보다 웰빙지향 행 동이 높았으며, 결혼상태에 따라 유의미한 차이를 보였다 $(t=-$ $4.14, p<0.001)$. 흡연여부별로는 담배를 피우지 않는 남성이 피 우는 남성보다 웰빙지향 행동이 높았으며, 흡연여부에 따라 유의

Table 4. Well-being oriented behavior

\begin{tabular}{|c|c|c|c|c|c|c|}
\hline Classification & & $\mathrm{N}$ & Mean & SD & $F$ or $t$ & $p$ \\
\hline \multirow{4}{*}{ Age } & $20 \mathrm{~s}$ & 70 & 2.10 & 0.59 & \multirow{4}{*}{$10.85^{* * *}$} & \multirow{4}{*}{0.000} \\
\hline & $30 \mathrm{~s}$ & 70 & 2.37 & 0.57 & & \\
\hline & $40 \mathrm{~s}$ & 53 & 2.37 & 0.53 & & \\
\hline & $50 s$ & 50 & 2.66 & 0.39 & & \\
\hline \multirow{3}{*}{ Academic background } & High school diploma or lower & 71 & 2.31 & 0.56 & \multirow{3}{*}{0.87} & \multirow{3}{*}{0.422} \\
\hline & Junior college graduate & 69 & 2.43 & 0.51 & & \\
\hline & University graduation or above & 103 & 2.33 & 0.60 & & \\
\hline \multirow{7}{*}{ Job } & Retail or service worker & 35 & 2.49 & 0.67 & \multirow{7}{*}{1.79} & \multirow{7}{*}{0.101} \\
\hline & Office manager/civil servant & 45 & 2.37 & 0.55 & & \\
\hline & Self-employed/business & 24 & 2.54 & 0.48 & & \\
\hline & Student & 31 & 2.13 & 0.59 & & \\
\hline & Production/technician & 65 & 2.30 & 0.49 & & \\
\hline & Profession & 22 & 2.40 & 0.68 & & \\
\hline & Others & 21 & 2.31 & 0.46 & & \\
\hline \multirow{5}{*}{ Monthly household income } & Under $1,000,000$ won & 33 & 2.10 & 0.59 & \multirow{5}{*}{$3.73^{* *}$} & \multirow{5}{*}{0.006} \\
\hline & $1,000,000-1,990,000$ won & 36 & 2.41 & 0.65 & & \\
\hline & $2,000,000-2,990,000$ won & 90 & 2.28 & 0.55 & & \\
\hline & $3,000,000-3,990,000$ won & 38 & 2.45 & 0.55 & & \\
\hline & Over 400,000 won & 46 & 2.54 & 0.43 & & \\
\hline \multirow{2}{*}{ Appearance of marital status } & Unmarried & 117 & 2.20 & 0.59 & \multirow{2}{*}{$-4.14^{* * *}$} & \multirow{2}{*}{0.000} \\
\hline & Married & 126 & 2.49 & 0.50 & & \\
\hline \multirow{2}{*}{ Smoking } & Non-smoker & 125 & 2.49 & 0.51 & \multirow{2}{*}{$4.22^{* * *}$} & \multirow{2}{*}{0.000} \\
\hline & Smoker & 118 & 2.20 & 0.58 & & \\
\hline \multirow{2}{*}{ Drinking } & Seldom drink & 89 & 2.38 & 0.58 & \multirow{2}{*}{0.60} & \multirow{2}{*}{0.552} \\
\hline & Drink & 154 & 2.33 & 0.56 & & \\
\hline \multirow{3}{*}{$\begin{array}{l}\text { Monthly average } \\
\text { beauty care costs }\end{array}$} & Under 100,000 won & 169 & 2.32 & 0.55 & \multirow{3}{*}{0.88} & \multirow{3}{*}{0.415} \\
\hline & Under $100,00-200,000$ won & 32 & 2.44 & 0.50 & & \\
\hline & Over 200,000 won & 42 & 2.41 & 0.66 & & \\
\hline \multirow{4}{*}{ Body type } & Endomorphy & 76 & 2.32 & 0.54 & \multirow{3}{*}{0.79} & \multirow{3}{*}{0.455} \\
\hline & Mesomorphy & 129 & 2.39 & 0.57 & & \\
\hline & Ectomorphy & 38 & 2.28 & 0.58 & & \\
\hline & Total & 243 & 2.35 & 0.56 & & \\
\hline
\end{tabular}

${ }^{*} p<0.01 ;{ }^{* * *} p<0.001$. 
미한 차이를 보였다 $(t=4.22, p<0.001)$. 음주여부별로는 술을 거 의 마시지 않는 남성이 마시는 남성보다 웰빙지향 행동이 높았으 나 통계적으로는 유의미한 차이를 보이지 않았다.

월평균 외모관리 비용별로는 10-20만원 미만인 남성이 웰빙 지향 행동이 가장 높았고, 10 만원 미만인 남성은 다른 남성보 다 웰빙지향 행동이 낮았으나 유의미한 차이는 아니었다. Jae \& Jeon (2007)연구에서는 $73.5 \%$ 가 웰빙을 즐기기 위해 한달에 10 만원에서 30 만원 정도 투자할 수 있다는 것으로 조사되었으 며, 이는 본 연구와 비교하여 보면 웰빙지향 행동이 높을수록 자 신의 건강과 행복한 삶을 위해 투자할 의지가 있다는 것을 알 수 있다. 체형별로는 중배엽 체형의 남성이 웰빙지향 행동이 가장 높았고, 외배엽 체형의 남성은 다른 체형의 남성보다 웰빙지향 행동이 낮았으나 체형에 따른 유의미한 차이가 없었다.
이상과 같이 성인 남성들은 웰빙지향 행동이 그다지 높지 않았 으며, 연령이 50 대인 남성과 월평균 소득이 400 만원 이상인 남 성, 기혼인 남성, 그리고 담배를 피우지 않는 남성이 다른 남성 보다 웰빙지향 행동이 높았다.

Yoo et al. (2012)의 연구에서 웰빙 행동에 영향을 미치는 요 인을 분석한 결과 연령이 높을수록, 학력이 높을수록, 자기관리 지출비용이 많을수록, 흡연을 하지 않을수록 웰빙 행동을 많이 하는 것으로 조사된 것은 본 연구 결과인 웰빙지향 행동과 비슷 한 결과를 나타내었다.

\section{3) 웰에이징 행위}

성인 남성들의 웰에이징 행위에 대해 살펴본 결과는 Table 5 와 같이 3 점 만점 중 전체 평균이 1.70 으로, 성인 남성들은 웰에

Table 5. Well-aging behavior

\begin{tabular}{|c|c|c|c|c|c|c|}
\hline Classification & & $\mathrm{N}$ & Mean & SD & For $t$ & $p$ \\
\hline \multirow{4}{*}{ Age } & $20 s$ & 70 & 1.78 & 0.49 & \multirow{4}{*}{$2.98^{*}$} & \multirow{4}{*}{0.032} \\
\hline & $30 \mathrm{~s}$ & 70 & 1.74 & 0.48 & & \\
\hline & $40 \mathrm{~s}$ & 53 & 1.54 & 0.39 & & \\
\hline & $50 s$ & 50 & 1.68 & 0.45 & & \\
\hline \multirow{3}{*}{ Academic background } & High school diploma or lower & 71 & 1.64 & 0.45 & \multirow{3}{*}{1.84} & \multirow{3}{*}{0.160} \\
\hline & Junior college graduate & 69 & 1.65 & 0.43 & & \\
\hline & University graduation or above & 103 & 1.76 & 0.50 & & \\
\hline \multirow{7}{*}{ Job } & Retail or service worker & 35 & 1.75 & 0.49 & \multirow{7}{*}{2.10} & \multirow{7}{*}{0.054} \\
\hline & Office manager/civil servant & 45 & 1.73 & 0.46 & & \\
\hline & Self-employed/business & 24 & 1.69 & 0.41 & & \\
\hline & Student & 31 & 1.81 & 0.58 & & \\
\hline & Production/technician & 65 & 1.61 & 0.38 & & \\
\hline & Profession & 22 & 1.85 & 0.52 & & \\
\hline & Others & 21 & 1.47 & 0.41 & & \\
\hline \multirow{5}{*}{ Monthly household income } & Under $1,000,000$ won & 33 & 1.72 & 0.59 & \multirow{5}{*}{0.85} & \multirow{5}{*}{0.497} \\
\hline & $1,000,000-1,990,000$ won & 36 & 1.71 & 0.48 & & \\
\hline & $2,000,000-2,990,000$ won & 90 & 1.64 & 0.44 & & \\
\hline & $3,000,000-3,990,000$ won & 38 & 1.80 & 0.46 & & \\
\hline & Over 400,000 won & 46 & 1.70 & 0.43 & & \\
\hline \multirow{2}{*}{ Appearance of marital status } & Unmarried & 117 & 1.76 & 0.49 & \multirow{2}{*}{$2.04^{*}$} & \multirow{2}{*}{0.042} \\
\hline & Married & 126 & 1.64 & 0.44 & & \\
\hline \multirow{2}{*}{ Smoking } & Non-smoker & 125 & 1.78 & 0.46 & \multirow{2}{*}{$2.97^{* *}$} & \multirow{2}{*}{0.003} \\
\hline & Smoker & 118 & 1.61 & 0.46 & & \\
\hline \multirow{2}{*}{ Drinking } & Seldom drink & 89 & 1.77 & 0.51 & \multirow{2}{*}{1.92} & \multirow{2}{*}{0.057} \\
\hline & Drink & 154 & 1.65 & 0.44 & & \\
\hline \multirow{3}{*}{$\begin{array}{l}\text { Monthly average } \\
\text { beauty care costs }\end{array}$} & Under 100,000 won & 169 & 1.64 & 0.46 & \multirow{3}{*}{$4.27^{*}$} & \multirow{3}{*}{0.015} \\
\hline & Under $100,000-200,000$ won & 32 & 1.73 & 0.39 & & \\
\hline & Over 200,000 won & 42 & 1.87 & 0.51 & & \\
\hline \multirow{4}{*}{ Body type } & Endomorphy & 76 & 1.58 & 0.46 & \multirow{3}{*}{$6.18^{* *}$} & \multirow{3}{*}{0.002} \\
\hline & Mesomorphy & 129 & 1.79 & 0.48 & & \\
\hline & Ectomorphy & 38 & 1.60 & 0.35 & & \\
\hline & Total & 243 & 1.70 & 0.47 & & \\
\hline
\end{tabular}

${ }^{*} p<0.05 ;{ }^{* * *} p<0.001$. 
이징 행위를 때때로 하는 것으로 나타났다.

연령별로는 20 대인 남성이 웰에이징 행위가 가장 높았고, 40 대인 남성은 다른 연령대 남성보다 웰에이징 행위가 낮았으며, 연령에 따라 유의미한 차이를 보였다 $(F=2.98, p<0.05)$. 학력별 로는 학력이 높은 남성일수록 웰에이징 행위가 높았으나 학력에 따른 유의미한 차이가 없었다. 직업별로는 전문직인 남성이 웰에 이징 행위가 가장 높았고, 기타 직업에 종사하는 남성은 다른 직 업에 종사하는 남성보다 웰에이징 행위가 낮았으나 통계적으로 는 유의미한 차이를 보이지 않았다.

월평균 소득별로는 300-399만원인 남성이 웰에이징 행위 가 가장 높았고, 200-299만원인 남성은 다른 남성보다 웰에이 징 행위가 낮았으나 유의미한 차이는 아니었다. Kim \& Shin (2018)연구에서는 월평균 수입이 200-300만원 미만, 400만원 이상의 경우 상대적으로 피부건강관리 교육경험이 많은 것으로 나타났으며, 특히 외모 때문에 스트레스를 받는 경우 상대적으로 피부건강관리 교육경험이 많은 것으로 나타났다.

결혼상태별로는 미혼인 남성이 기혼인 남성보다 웰에이징 행위가 높았으며, 결혼상태에 따라 유의미한 차이를 보였다 $(t=2.04, p<0.05)$. 흡연여부별로는 담배를 피우지 않는 남성이 피우는 남성보다 웰에이징 행위가 높았으며, 흡연여부에 따라 유 의미한 차이를 보였다 $(t=2.97, p\langle 0.01)$. 음주여부별로는 술을 거의 마시지 않는 남성이 마시는 남성보다 웰에이징 행위가 높았 으나 음주여부에 따른 유의미한 차이가 없었다. 월평균 외모관리 비용별로는 월평균 외모관리로 많은 비용을 지출하는 남성일수 록 웰에이징 행위가 높았으며, 월평균 외모관리비용에 따라 유의 미한 차이를 보였다 $(F=4.27, p<0.05)$. 체형별로는 중배엽 체형 의 남성이 웰에이징 행위가 가장 높았고, 내배엽 체형의 남성은
다른 체형의 남성보다 웰에이징 행위가 낮았으며, 체형에 따라 유의미한 차이를 보였다 $(F=6.18, p<0.01)$.

이상과 같이 성인 남성들은 웰에이징 행위를 때때로 하였으며, 연령이 20 대인 남성과 미혼인 남성, 담배를 피우지 않는 남성, 월평균 외모관리로 많이 지출하는 남성일수록, 그리고 중배엽 체 형의 남성이 다른 남성보다 웰에이징 행위가 높았다.

Yim \& Kim (2014)연구에서도 연령이 적은 남성일수록 피부 건강관리 지식이 높은 것으로 본 연구와 비교하여 보았을 때 나 이가 어린 남성일수록 피부지식이 높으며 그에 따른 웰에이징 행 위가 달라진다는 것을 알 수 있다. Yu \& Im (2015)연구에서는 자기의식이 높으면 안면 피부관리 행동도 높아진다는 연구결과 를 통하여 상관관계를 나타나냈다.

\section{3. 미용관리와 웰빙지향 행동 및 웰에이징 행위와의 관계}

1) 미용관리와 웰빙지향 행동과의 관계

성인 남성들의 미용관리와 웰빙지향 행동과의 관계에 대해 살 펴본 결과는 Table 6 에서 보는 바와 같이 미용관리는 웰빙지향 행동과 통계적으로 유의미한 정적 상관관계를 보였다 $(\mathrm{r}=0.507$, $p<0.001)$. 따라서 성인 남성들은 미용관리를 많이 할수록 웰빙 지향 행동이 높음을 알 수 있다.

\section{2) 미용관리와 웰에이징 행위와의 관계}

성인 남성들의 미용관리와 웰에이징 행위와의 관계에 대해 살 펴본 결과 Table 7 에서 보는 바와 같이 미용관리는 웰에이징 행 위와 통계적으로 유의미한 정적 상관관계를 보였다 $(\mathrm{r}=0.614$, $p<0.001)$. 따라서 성인 남성들은 미용관리를 많이 할수록 웰에 이징 행동이 높음을 알 수 있다.

Table 6. The relationship between beauty care and well-being-oriented behavior

\begin{tabular}{lc}
\hline Classification & Well-being oriented behavior \\
Beauty care & $0.507^{* * *}(0.000)$ \\
\hline${ }^{* * *} p<0.001$. &
\end{tabular}

Table 7. The relationship between beauty care and well-aging behavior

\begin{tabular}{lc}
\hline Classification & Well-aging behavior \\
Beauty care & $0.614^{* * *}(0.000)$ \\
\hline${ }^{* * *} p<0.001$. &
\end{tabular}

Table 8. The effect of beauty management on well-being-oriented behavior

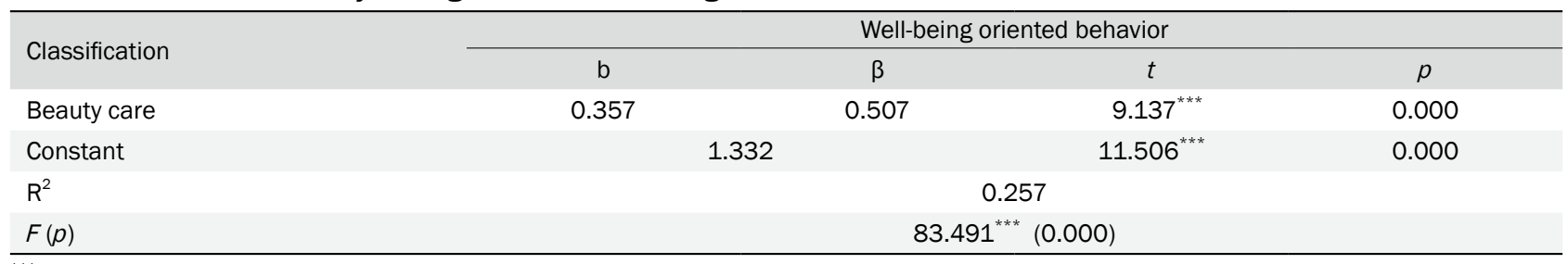

${ }^{* * *} p<0.001$. 


\section{4. 미용관리가 웰빙지향 행동과 웰에이징 행위에 미치는 영향}

1) 미용관리가 웰빙지향 행동에 미치는 영향

성인 남성들의 미용관리가 웰빙지향 행동에 미치는 영향을 살 펴본 결과는 Table 8 과 같다. 성인 남성들의 미용관리가 웰빙 지향 행동에 미치는 영향을 살펴보면, 이 모형은 적합성이 검 증되었으며 $(F=83.491, p<0.001)$, 약 $25.7 \%\left(\mathrm{R}^{2}=0.257\right)$ 를 설 명해주고 있다. 성인 남성들의 웰빙지향 행동에는 미용관리 $(\beta=0.507, p<0.001)$ 가 통계적으로 유의미한 정 $(+)$ 의 영향을 미 쳤다. 따라서 성인 남성들은 미용관리를 많이 할수록 웰빙지향 행동이 높음을 알 수 있다.

\section{2) 미용관리가 웰에이징 행위에 미치는 영향}

성인 남성들의 미용관리가 웰에이징 행위에 미치는 영향을 살 펴본 결과는 Table 9 와 같다. 성인 남성들의 미용관리가 웰에 이징 행위에 미치는 영향을 살펴보면, 이 모형은 적합성이 검 증되었으며 $(F=145.927, p<0.001)$, 약 $37.7 \%\left(\mathrm{R}^{2}=0.377\right)$ 를 설명해주고 있다. 성인 남성들의 웰에이징 행위에는 미용관리 $(\beta=0.614, p<0.001)$ 가 통계적으로 유의미한 정 $(+)$ 의 영향을 미 쳤다. 따라서 성인 남성들은 미용관리를 많이 할수록 웰에이징 행위가 높음을 알 수 있다.

\section{Conclusion}

본 연구는 성인 남성의 미용관리가 웰빙지향 행동과 웰 에이징 행위에 미치는 영향을 알아보고자 경북지역의 성인남성을 대상 으로 설문지법을 통하여 수집된 자료 243 부를 연구에 사용하였 다.

연구결과는 다음과 같다. 조사대상자의 일반적 특성으로는 총 243 명 중 연령별로는 20 대와 30 대가 각각 $28.8 \%$ 를 차지하였 고, 40 대는 $21.8 \%, 50$ 대는 $20.6 \%$ 이었다.

성인 남성들은 미용관리가 5점 만점 중 전체 평균이 2.85 로, 그다지 높지 않은 것으로 나타났으며 그중 20대 남성과 학생이 미용관리가 가장 높았고, 40 대 남성은 다른 연령대 남성보다 미 용관리가 낮았다. 월평균 소득별로는 300 만원 이상인 남성과 미 혼인 남성이 기혼인 남성보다 미용관리가 높았다. 월평균 외모관
리 비용별로는 10-20만원 미만인 남성이 미용관리가 가장 높았 고 $(F=4.15, p<0.05)$, 체형별로는 중배엽 체형의 남성이 미용관 리가 가장 높았다 $(F=8.45, p<0.001)$.

성인 남성들의 웰빙지향 행동은 그다지 높지 않은 것으로 나 타났으며 그중 50 대인 남성이 웰빙지향 행동이 가장 높았고, 20 대인 남성은 다른 연령대 남성보다 웰빙지향 행동이 낮았다 $(F=10.85, p<0.001)$. 월평균 소득별로는 400 만원 이상인 남 성이 웰빙지향 행동이 가장 높았고 $(F=3.73, p<0.01)$, 기혼인 남성이 미혼인 남성보다 웰빙지향 행동이 높았으며 $(t=-4.14$, $p<0.001)$, 담배를 피우지 않는 남성이 피우는 남성보다 웰빙지 향 행동이 높았다 $(t=4.22, p<0.001)$.

성인 남성들은 웰에이징 행위를 때때로 하는 것으로 나타났다. 20대인 남성이 웰에이징 행위가 가장 높았고, 40 대인 남성은 다 른 연령대 남성보다 웰에이징 행위가 낮았다 $(F=2.98, p<0.05)$. 직업별로는 전문직인 남성과, 학력별로는 학력이 높은 남성일수 록 웰에이징 행위가 높았다. 월평균 소득별로는 300-399만원 인 남성이 웰에이징 행위가 가장 높았고, 200-299만원인 남성 은 다른 남성보다 웰에이징 행위가 낮았다. 미혼인 남성이 기혼 인 남성보다 웰에이징 행위가 높았으며 $(t=2.04, p<0.05)$, 담배 를 피우지 않는 남성이 피우는 남성보다 웰에이징 행위가 높은 $(t=2.97, p<0.01)$ 것으로 나타났다. 월평균 외모관리로 많은 비 용을 지출하는 남성일수록 웰에이징 행위가 높았으며 $(F=4.27$, $p<0.05)$, 체형별로는 중배엽 체형의 남성이 웰에이징 행위가 가장 높았고, 내배엽 체형의 남성은 다른 체형의 남성보다 웰 에이징 행위가 낮았으며, 체형에 따라 유의미한 차이를 보였다 $(F=6.18, p<0.01)$.

\section{1. 미용관리와 웰빙지향 행동 및 웰에이징 행위와의 관계를 알아 본 결과 다음과 같다.}

성인 남성들의 미용관리는 웰빙지향 행동과 통계적으로 유의 미한 정적 상관관계를 보였으며 $(\mathrm{r}=0.507, p<0.001)$, 미용관리 를 많이 할수록 웰빙지향 행동이 높음을 알 수 있었고, 미용관리 는 웰에이징 행위와 통계적으로 유의미한 정적 상관관계를 보였 으며 $(\mathrm{r}=0.614, p<0.001)$, 미용관리를 많이 할수록 웰에이징 행 동이 높음을 알 수 있다.

Table 9. The effect of beauty management on well-aging behavior

\begin{tabular}{|c|c|c|c|c|}
\hline \multirow{2}{*}{ Classification } & \multicolumn{4}{|c|}{ Well-aging behavior } \\
\hline & $\mathrm{b}$ & $\beta$ & $t$ & $p$ \\
\hline Beauty care & 0.357 & 0.614 & $12.080^{* * *}$ & 0.000 \\
\hline Constant & & & $7.734^{* * *}$ & 0.000 \\
\hline $\mathrm{R}^{2}$ & \multicolumn{4}{|c|}{0.377} \\
\hline$F(p)$ & \multicolumn{4}{|c|}{$145.927^{* * *}(0.000)$} \\
\hline
\end{tabular}

${ }^{* * *} p<0.001$. 


\section{2. 미용관리가 웰빙지향 행동과 웰에이징 행위에 미치는 영향 알 아본 결과 다음과 같다.}

성인 남성들의 웰빙지향 행동에는 미용관리 $(\beta=0.507$, $p<0.001)$ 가 통계적으로 유의미한 정 $(+)$ 의 영향을 미친 것으로 성인 남성들은 미용관리를 많이 할수록 웰빙지향 행동이 높음을 알 수 있었고, 웰에이징 행위에는 미용관리( $\beta=0.614, p<0.001)$ 가 통계적으로 유의미한 정(+)의 영향을 미친 것으로 성인 남성 들은 미용관리를 많이 할수록 웰에이징 행위가 높음을 알 수 있 다.

몸과 마음의 건강으로 아름다운 삶을 추구하여 사회 전반적 생 활 수준을 향상시키기 위하여 올바른 웰빙(well-being)인식과 미용관리가 필요하다는 것을 알 수 있다. 본 연구는 연구대상자 의 지역적 한계와 소수의 대상인원으로 이를 일반화 하기에 무리 가 있으며 후속 연구에서는 더 많은 지역과 인원 그리고 조금 더 다양한 연령의 확대가 필요할 것이다.

\section{Acknowledgements}

This research was supported by the Daejeon University Research Grants (2018).

\section{References}

Chung UJ. A study on attitude and characteristics towards appearance care of adult male. Journal of the Korean Society of Beauty and Art, 12: 27-45, 2011.

Hong JK. A study on skin recognition and cosmetics use necessity in men by age. Journal of the Korean Society of Cosmetology, 14: 1230-1243, 2008.

Hong S. Effect of unmarried men's lifestyle category on beauty behavior consci. Journal of Basic Design \& Art, 14: 441-447, 2013.

Hong SN, Kim HS. Effects of extrinsic body satisfaction on beauty management behavior of women of age 20-40. Asian Journal of Beauty and Cosmetology, 10: 829-836, 2012.

Hwang AH, Kang JW, Han SS. Analysis of university students' experience on cosmetic surgery and skin care. Journal of Investigative Cosmetology, 13: 125-132, 2017.

Jae MK, Jeon HR. A study on the well-being food consumption behaviors and the well-being oriented consumption values. Family and Environment Research, 45: 63-74, 2007.

Jeon HR, Jae MK. Consumer consciousness toward well- being and well-being oriented consumer behaviors according to the dietary life: focused on purchasing, using, and disposal behavior of married women. Korean Journal of Human Ecology, 16: 957-967, 2007.

Jeong $\mathrm{H}$, Kim S. The study of somatotype characteristics of muscular men. Korean Journal of Human Ecology, 17: 315-334, 2008.

Kim MJ, Kim BS. Causal model of well-being oriented behavior. Journal of Consumption Culture, 11: 43-62, 2008.

Kim MS, Jeon HJ, Kang SK. The influence of well-being perception on appearance management behavior of new senior woman's. Journal of the Korean Society of Cosmetology, 18: 688-697, 2012.

Kim SE, Kim MS. A study of the knowledge and management of skin health among the male adults in Korean society. Journal of the Korean Society of Esthetic \& Cosmeceutics, 1: 121-133, 2006.

Kim SHB, Youn CS. A study on beauty care tendency. Journal of The Korean Society of Cosmetology, 13: 1413-1420, 2007.

Kim Y, Cho KM. A study on the effect factors of male and female college students in cosmetic management intention and weight management intention. Journal of The Korean Society of Cosmetology, 16: 244-253, 2010.

Kim Yh, Shin KO. A study on knowledge, attitude and educational needs for skin health care of male university college students. Journal of The Korean Society of Cosmetology, 24: 207-216, 2018.

Kim YR. A study on the interest for beauty care according to gender. Journal of The Korean Society of Cosmetology, 13: 1321-1329, 2007.

Kwock CK, Jang JK. The promotion strategies of wellbeing food industry: focusing on fresh-cut produce industry. Food Industry and Nutrition, 13: 17-27, 2008.

Kwon HJ. The effect of self skin care on man's skin condition change. Journal of the Korean Society of Cosmetology, 22: 308-318, 2016.

Lim GE, Kang SY, Kim YK, Kim HW, Park TJ, Kim J, Lee K. Secular trends for body-shape perception, weightloss efforts, and weight-loss behaviors in Korean adults using the Korea national health and nutrition examination survey from 2001 to 2014 . Korean Journal 
of Health Promotion, 17: 31-37, 2017.

Lim SH, Kim SH. 30-40 Men's lifestyle and skin care act influence of the cosmetic purchase form. Asian Journal of Beauty and Cosmetology, 13: 517-526, 2015.

Park SK. A study on sociocultural attitude toward appearance and appearance management intention of male consumer : focusing on media exposure. Journal of the Korean Society of Cosmetology, 21: 614-620, 2015.

Yim SH, Kim MS. A study on attitudes toward man's appearance management and cosmetics purchasing behavior. Journal of the Korean Fashion \& Costume Design Association, 16: 79-98, 2014.
Yoo SJ, Cho SH, HwangBo G. Well-being levels and wellbeing behavior, and its related factors among women in Daegu city. Journal of the Korea Academia-Industrial cooperation Society, 13: 3065-3073, 2012.

Yu H, Ko S. Development of a appearance related quality of life instrument for Korean men and investigation on body factors influencing appearance related quality of life. Fashion and Textile Research Journal, 18: 595-605, 2016.

Yu J, Im EJ. Effects of the self-consciousness on facial skin care behaviors of male adults in their 20 s to 40 s. Journal of Investigative Cosmetology, 11: 277-283, 2015. 


\section{국문초록}

\section{성인 남성의 미용관리가 웰빙지향 행동과 웰에이징 행위에 미치는 영향}

박재영, 이명선

대전대학교 뷰티건강관리학과, 대전, 한국

목적: 본 연구는 성인 남성의 미용관리가 웰빙지향 행동과 웰에이징 행위에 미치는 영향을 알아봄으로써 건강한 마음과 몸을 통하 여 삶의 질이 향상되는 방안을 모색하고자 하였다. 방법: 본 연구의 수집된 자료는 SPSS 프로그램을 이용하여 분석하였다. 분석기 법으로는 연구대상자의 일반적 특성을 파악하기 위해 빈도와 백분율을 산출하였고, 성인 남성들의 미용관리와 웰빙지향 행동, 그리 고 웰에이징 행위를 살펴보기 위해 일원변량분석(one-way ANOVA)과 $t$-test 검증과 회귀분석을 실시하였다. 결과: 성인 남성들의 미용관리는 웰빙지향 행동과 통계적으로 유의미한 정적 상관관계를 보였으며( $\mathrm{r}=0.507, p<0.001)$ 미용관리를 많이 할수록 웰빙지향 행동이 높음을 알 수 있었고, 미용관리는 웰에이징 행위와 통계적으로 유의미한 정적 상관관계를 보였으며 $(\mathrm{r}=0.614, p<0.001)$ 미용 관리를 많이 할수록 웰에이징 행동이 높음을 알 수 있다. 성인 남성들의 웰빙지향 행동에는 미용관리 $(\beta=0.507, p<0.001)$ 가 통계적 으로 유의미한 정(+)의 영향을 미친 것으로 성인 남성들은 미용관리를 많이 할수록 웰빙지향 행동이 높음을 알 수 있었다. 결론: 본 연구를 통하여 나이가 어릴수록 미용관리와 웰에이징에 더욱 관심을 가지고 신경을 쓰고 있다는 것을 알 수 있었으며, 미용관리를 많이 할수록 웰에이징 행위가 높고, 웰빙지향 행동이 높다는 상관관계를 알 수 있다. 몸과 마음의 건강으로 아름다운 삶을 추구하여 사회 전반적 생활 수준을 향상시키기 위하여 올바른 웰빙(well-being)인식과 미용관리가 필요하다고 사료된다.

핵심어: 웰에이징 행위, 미용관리, 웰에이징, 웰빙인식, 웰빙지향행동

This research was supported by the Daejeon University Research Grants (2018).

\section{참고문헌}

곽창근, 장종근. 웰빙식품산업 활성화 방안: 신선편의식품 시장을 중심으로. 식품산업과 영양, 13: 17-27, 2008.

권혜진. 안면 자가 피부 관리 행동이 남성 피부상태 개선에 미치는 영향. 한국미용학회지, 22: 308-318, 2016.

김명숙, 전현진, 강수경. 뉴 시니어 여성의 웰빙인식이 외모관리행동에 미치는 영향. 한국미용학회지, 18: 688-697, 2012.

김민정, 김병숙. 웰빙지향행동의 인과모형. 소비문화연구, 11: 43-62, 2008.

김새한별, 윤천성. 미용관리성향에 관한 연구. 한국미용학회지, 13: 1413-1420, 2007.

김숙은, 김명숙. 성인 남성의 피부지식과 피부건강관리 행위에 관한 연구. 한국피부미용향장학회지, 1: 121-133, 2006. 김영란. 성별에 따른 미용관리 관심도에 관한 연구. 한국미용학회지, 13: 1321-1329, 2007.

김영희, 신규옥. 남자대학생의 피부건강관리 지식, 태도 및 교육 요구도에 관한 연구. 한국미용학회지, 24: 207-216, 2018.

김윤, 조고미. 남녀 대학생의 성별에 따른 미용관리 및 체중관리에 대한 영향요인 분석. 한국미용학회지, 16: 244-253, 2010.

박수경. 남성의 외모에 사회문화적 태도와 외모관리 수행의도에 관한 연구: 미디어노출도를 중심으로. 한국미용학회지, 21: 614-620, 2015.

유수정, 조성현, 황보각. 대구지역 거주 여성들의 웰빙 수준 및 웰빙 행동에 관한 요인. 한국산학기술학회논문지, 13 : 3065-3073, 2012.

유진, 임은진, 20 40대 남성의 자기의식이 안면 피부관리 행동에 미치는 영향. 대한미용학회지, 11: 277-283, 2015. 
유혜경, 고선영. 한국 남성들의 외모 관련 삶의 질 척도 개발 및 외모 관련 삶의 질에 영향을 미치는 신체요인 분석. 한국의 류산업학회지, 18: 595-605, 2016.

임경은, 강선영, 김양근, 김혜원, 박태진, 김진승, 이가영. 한국 성인에서 체형인식과 체중감량 노력 및 체중감량 행동의 14년간 추세: 2001년에서 2014까지 국민건강영양조사 자료. 대한임상건강증진학회지, 17: 31-37, 2017.

임선형, 김성희. 30-40대 남성의 생활습관과 피부관리 행동이 화장품 구매형태에 미치는 영향. 아시안뷰티화장품학술지, 13: 517-526, 2015.

임수현, 김민신. 남성들의 미용에 대한 관심과 화장품 구매행동 연구. 한국의상디자인학회지, 16: 79-98, 2014.

전향란, 제미경. 웰빙식생활에 대한 소비자인식과 웰빙지향 소비자행동: 기혼여성 소비자의 구매, 사용, 처분행동을 중심 으로. 한국생활과학회지, 16: 957-967, 2007.

정의정. 성인 남성의 외모관리행동과 특성에 관한 연구. 한국인체미용예술학회지, 12: 27-45, 2011.

정혜진, 김소라. 근육형 남성의 체형특성에 관한 연구. 한국생활과학회지, 17: 315-334, 2008.

제미경, 전향란. 식생활관련 웰빙지향 소비가치와 웰빙식품 소비행동. 대한가정학회지, 45: 63-74, 2007.

홍수남, 김효숙. 20-40대 여성의 외모만족도가 미용관리태도에 미치는 영향. 아시안뷰티화장품학술지, 10: 829-836, 2012.

홍수남. 미혼남성의 라이프스타일 유형이 뷰티행동인식에 미치는 영향. 기초조형학연구, 14: 441-447, 2013.

홍재기. 성인남성의 연령에 따른 피부인지도 및 화장품 사용 필요성에 관한 연구. 한국미용학회지, $14: 1230-1243$, 2008.

황애화, 강지웅, 한삼성. 대학생들의 미용성형 및 피부미용 경험에 미치는 요인. 대한미용학회지, 13: 125-132, 2017. 


\section{中文摘要}

\section{美容护理对成年男性幸福感行为和老龄化行为的影响}

朴栽瑩, 李明宣

大田大学美容健康管理，大田，韩国

目的: 通过调查成年男性的美容管理对幸福感行为和老龄化行为的影响，探索通过健康的身心找到改善生活质量 的方案。方法: 收集的数据通过SPSS程序进行分析。主要分析方法是为分析研究对象的一般特征利用频率和百 分比分析, 为分析 进行单因素方差分析, $t$ 检验和回归分析以确定美容护理对健康导向和良好老化行为的功效。 结果: 成年男性的美容护理方案与健康导向和老化行为呈显着正相关 $(r=0.507, p<0.001 ; r=0.614, p<0.001)$; 更多的美容护理导致更好的健康导向和老化的行为。结论: 调查结果表明，年轻男性更关心美容护理和老龄化， 美容护理与老龄化行为和健康导向行为相关。正确的健康意识和适当的美容护理对于确保身心健康, 提高整个 社会的生活水平，追求幸福健康的生活是必要的。

关键词: 老龄化行为，美容护理，老龄化，健康意识，健康导向行为 